\title{
Uji Patogenisitas Isolat Bakteri Indigenous (Bacillus thuringiensis) terhadap Serangga Hama Kubis (Crocidolomia binotalis Zell)
}

\author{
Pathogenicity Test of Indigenous Bacterial Isolate (Bacillus thuringiensis) Against Insect \\ Pest of Cabagge (Crocidolomia binotalis Zell)
}

\section{Christina L. Salaki ${ }^{1 *}$, Jesmandt Situmorang ${ }^{2}$, Langkah Sembiring ${ }^{3}$, Niken S.N. Handayani $^{4}$}

${ }^{1}$ Jurusan Hama dan Penyakit Tumbuhan, Fakultas Pertanian, Unsrat, Manado

${ }^{2}$ Laboratorium Entomologi, Fakultas Biologi Universitas Gadjah Mada, Yogyakarta

${ }^{3}$ Laboratorium Mikrobiologi, Fakultas Biologi Universitas Gadjah Mada, Yogyakarta

${ }^{4}$ Laboratorium Genetika, Fakultas Biologi Universitas Gadjah Mada, Yogyakarta

E-mail: christinasalaki@ymail.com *Penulis untuk korespondensi

\begin{abstract}
Pathogenicity of 34 indigenous $B$. thuringiensis isolates against $C$. binotalis were determined. The pathogenicity test was conducted by using leaf dipped method with various spore concentrations. Third instar larvae of $C$. binotalis were used as insect test. Mortality data of test larvae were used to determine the pathogenicity of the isolates in terms of 72 hours $\mathrm{LC}_{50}$ by using probit analysis. The results of experiments showed YPPA 1. was the most pathogenic isolate, producing 72 hours $L_{50}=9.5 \times 10^{3}$ spore. $\mathrm{ml}^{-1}$ with $\mathrm{LT}_{50}\left(1.5 \times 10^{7}\right.$ spore. $\left.\mathrm{ml}^{-1}\right)$ of 24.6 hours while the ACH 2.3 was found to be the least pathogenic isolate with 72 hours $\mathrm{LC}_{50}=2.3 \times 10^{6}$ spore.ml $^{-1}$ and $\mathrm{LT}_{50}$ $\left(1.5 \times 10^{7}\right.$ spoore.ml $\left.{ }^{-1}\right)$ of 40.7 hours. The shortest $\mathrm{LT}_{50}\left(1.5 \times \mathbf{1 0}^{7}\right.$ spore.ml $^{-1}$ was found to be 18.2 hours produced by TUS.1 with 72 hours $\mathrm{LC}_{50}=3.9 \times 10^{5}$ spore. $^{-1}$ whereas the longest $\mathrm{LT}_{50}\left(1.5 \times 10^{7}\right.$ spore. $\left.^{-1}\right)$ was found tobe 83.2 hours produced by the SLK 4.1 with 72 hours $\operatorname{LC}_{50}=3.1 \times 10^{4}$ spore. $\mathrm{ml}^{-1}$. Therefore, it can be concluded that both YPPA.1 and TUS.1 isolates are potential candidate to be developed for biological control agent.
\end{abstract}

Key words: Pathogenicity, Bacillus thuringiensis, Crocidolomia binotalis, Mortality

Diterima: 02 Februari 2009, disetujui: 18 September 2009

\section{Pendahuluan}

Kubis (Brassicae oleraceae var. capitata) merupakan sayuran yang mengandung vitamin, mineral, protein, karbohidrat dan lemak untuk pembentukan jaringan tubuh manusia dan meningkatkan energi untuk aktivitas otot-otot manusia. Sebagai sumber vitamin, kubis mengandung vitamin $\mathrm{A}, \mathrm{B}$ dan $\mathrm{C}$, niacin dan mineral, di antaranya kapur, phosphor, zat besi dan belerang (Schellhorn, 2001; Untung, 2001; Cahyono, 2002; Unjianto, 2004).

Berbagai usaha telah dilakukan untuk meningkatkan produksi kubis, antara lain dengan intensifikasi dan ekstensifikasi. Dalam usaha meningkatkan produksi kubis ini banyak faktor penghambat yang harus dihadapi antara lain adalah gangguan hama dan penyakit. Salah satu faktor penting yang harus mendapat perhatian adalah pengendalian hama.

Ulat krop kubis (Crocidolomia binotalis) merupakan hama utama tanaman kubis di daerah pegunungan di Indonesia. Secara historis dilaporkan bahwa sejak tahun 1916 ulat pemakan daun telah menimbulkan kerusakan berat pada pertanaman kubis di Jawa, Bali, Sumatera, Sulawesi dan banyak daerah lain (Sudarwohadi, 1975). Hasil penelitian di Indonesia menunjukkan serangan hama $C$. binotalis dan Plutella xylostella pada tanaman 
kubis yang ditanam pada bulan Juli (pertengahan musim kemarau) menyebabkan kehilangan hasil sampai $100 \%$ apabila tidak dikendalikan (Sudarwohadi, 1975; Kalshoven, 1981; Pracaya, 1992). Pada tanaman yang telah membentuk krop, ulat ini menyerang terutama pada bagian dalam yang terlindung daun hingga mencapai titik tumbuh. Jika serangan ini ditambah dengan serangan penyakit, tanaman dapat mati karena bagian dalamnya menjadi busuk meskipun dari luar masih terlihat baik sehingga menyebabkan tanaman kubis gagal membentuk krop dan gagal panen (Kalshoven, 1981; Hoofman dan Frodsham, 1993; Sudarwohadi dan Setiawati, 2000; Capinera, 2000; Harjaka dan Suryanto, 2002).

Upaya pengendalian ulat $C$. binotalis yang sampai saat ini masih sering dilakukan adalah dengan penggunaan insektisida kimiawi. Penggunaan insektisida kimiawi, baik dalam bidang kesehatan maupun pertanian secara terus menerus terbukti menimbulkan dampak negatif yaitu terjadinya resistensi serangga vektor atau serangga hama, resurgensi hama, ledakan hama sekunder, dan pencemaran lingkungan serta terakumulasinya residu pestidida kimiawi dalam tanaman sehingga berbahaya bagi manusia dan berbagai spesies hewan yang memakannya (Untung, 1996). Mengingat besarnya bahaya yang dapat ditimbulkan oleh pemakaian insektisida kimiawi tersebut, maka perlu dicari teknik pengendalian alternatif yang lebih aman yaitu penggunaan musuh alami yaitu parasit, predator dan patogen.

Salah satu jenis patogen yang berpotensi untuk mengendalikan hama krop kubis adalah berbagai strain bakteri anggota spesies Bacillus thuringiensis (Burges dan Hussey, 1981; Bahagiawati, 2002). Strain anggota $B$. thuringiensis merupakan agensia hayati yang bersifat entomopatogenik, mempunyai hospes yang spesifik, tidak berbahaya bagi musuh alami hama dan organisme non target lainnya, mudah terbiodegradasi oleh lingkungan, serta dapat dinaikkan patogenisitasnya dengan teknik rakayasa genetik (Khetan, 2001; Trizelia, 2003).

Berdasarkan pertimbangan sifat-sifat unggul yang dimiliki oleh strain bakteri $B$. thuringiensis ini perlu dilakukan ekplorasi bakteri tersebut dari habitat lokal Indonesia untuk selanjutnya diuji patogenisitasnya terhadap ulat krop kubis (C. binotalis). Penelitian eksplorasi strain $B$. thuringiensis endogen Indonesia telah berhasil memperoleh sebanyak 1238 isolat yang 161 di antaranya telah diuji potensi daya bunuhnya terhadap ulat krop kubis, dan ternyata 101 isolat terbukti potensial membunuh serangga hama ulat krop kubis karena mampu menimbulkan mortalitas $\geq 50 \%$ serangga uji (Salaki et al., 2009a).

Penelitian ini bertujuan memperoleh isolat unggul di antara isolat potensial yang dapat digunakan sebagai kandidat biopestisida hayati ramah lingkungan. Kriteria keunggulan dinyatakan berdasarkan nilai patogenisitas isolat $B$. thuringiensis terhadap ulat $C$. binotalis dalam bentuk nilai $\mathrm{LC}_{50}$ dan $\mathrm{LT}_{50}$.

\section{Metode Penelitian}

\section{Tempat dan Waktu Penelitian}

Penelitian dilaksanakan di Laboratorium Entomologi Fakultas Biologi Universitas Gadjah Mada Yogyakarta, mulai bulan September 2007 sampai Oktober 2008.

\section{Pemeliharaan Serangga Uji}

Ulat $C$. binotalis sebagai serangga uji diperoleh dari kebun kubis di desa Kopeng, Kecamatan Getasan, Kabupaten Semarang (Jawa Tengah). Pemeliharaannya di laboratorium dengan pemberian pakan daun kubis segar, sampai diperoleh ulat instar III yang digunakan untuk pengujian.

\section{Isolat Bakteri Uji}

Bakteri yang digunakan dalam penelitian ini adalah 34 isolat di antara 101 isolat potensial (Salaki et al., 2009a) yang dapat menimbulkan mortalitas ulat C. binotalis $>50 \%$ pada waktu pendedahan 24 jam dengan konsentrasi $1,5 \times 10^{7} \mathrm{spora} / \mathrm{ml}$.

\section{Uji Patogenisitas B. thuringiensis}

Pengujian patogenisitas isolat $B$. thuringiensis terhadap ulat $C$. binotalis bertujuan untuk mengetahui kemampuan isolatisolat tersebut menginfeksi dan menimbulkan kematian dengan konsentrasi yang bervariasi. 
Uji patogenisitas menggunakan metode pencelupan daun (leaf dipped method) ke dalam suspensi (spora bakteri dalam larutan Ringer steril) $B$. thuringiensis pada lima variasi konsentrasi $\left(1,5 \times 10^{7} ; 1,5 \times 10^{6} ; 1,5 \times 10^{5} ; 1,5\right.$ x $10^{4} ; 1,5 \times 10^{3}$ spora/ml). Kontrol dilakukan dengan pencelupan daun ke dalam larutan Ringer streril tanpa spora bakteri. Pengamatan mortalitas dilakukan pada waktu pendedahan 12, 24. 48, 72 dan 96 jam untuk melihat pengaruh perlakuan yang diujikan. Data mortaliatas dikoreksi dengan formula Abbot (Finney, 1971) bila ada kematian pada kontrol.

\section{Analisis Data}

Data mortalias yang diperoleh digunakan untuk menentukan nilai patogenisitas isolat bakteri yang diuji. Patogenisitas setiap isolat dinyatakan dengan $\mathrm{LC}_{50}$ dan $\mathrm{LT}_{50}$ pada pendedahan 72 jam yang dihitung dengan menggunakan metode Analisis Probit (Finney, 1971).

\section{Hasil dan Pembahasan}

\section{Uji Patogenisitas}

Inokulum untuk pengujian menggunakan isolat berumur 2-5 hari karena pada umur tersebut bakteri telah membentuk spora dan kristal parasporal yang merupakan bahan toksin terhadap serangga. Hasil pengujian secara umum menunjukkan bahwa mortalitas larva uji meningkat seiring dengan kenaikan jumlah spora yang dipergunakan. Dengan semakin meningkatnya konsentrasi spora maka jumlah spora dan kristal parasporal yang tertelan oleh larva juga semakin banyak sehingga dapat menimbulkan kematian pada serangga yang disebabkan oleh kerusakan fungsi epitel midgud (Hoffman et al., 1988; Bajwa dan Kogan, 2001) juga semakin besar.

Hasil penelitian menunjukkan bahwa pada pengamatan 12 jam waktu pendedahan ditemukan hanya isolat SLK4.2 yang dapat membunuh larva uji pada konsentrasi terendah $\left(1,5 \times 10^{3} \mathrm{spora} / \mathrm{ml}\right)$ dengan nilai mortalitas 3,33 . Demikian pula pada konsentrasi tertinggi $\left(\begin{array}{llll}1,5 & \mathrm{x} & 10^{7} & \mathrm{spora} / \mathrm{ml}) \\ \end{array}\right.$ menunjukkan kemampuan membunuh tertinggi yaitu dengan nilai mortalitas $30 \%$. Selanjutnya, pada pengamatan waktu pendedahan 96 jam, konsentrasi terendah isolat ini (SLK4.2) juga mampu menimbulkan mortalitas urutan ketiga tertinggi $(53,3 \%)$ setelah isolat YPPA1 $(56,67 \%)$ dan isolat BAU6.2 (60\%). Namun demikian, pada konsentrasi tertinggi dengan waktu pendedahan 96 jam semua isolat mampu menimbulkan mortalitas yang tinggi yaitu 80 $100 \%$. Hal yang menarik untuk dikemukakan bahwa ternyata ada 9 isolat (BAU6.2, BLPPN5.3, LPST1, LPSU4, SRNG2.4, SRNG1.3, TUS1, YPPA1, dan YWKA1) yang dapat dianggap unggul karena mampu menimbulkan mortalitas sampai $100 \%$.

Selanjutnya, pengujian isolat-isolat tersebut memperlihatkan bahwa pengamatan 6 jam setelah perlakuan meskipun larva belum mengalami kematian akan tetapi sudah mulai terlihat adanya gejala terinfeksi. Terdapat bekas gigitan pada pakan dan butiran-butiran faeces pada dasar botol. Hal ini menandakan bahwa larva uji telah memakan daun kubis yang mengandung bakteri. Perilaku larva yang terinfeksi adalah bergerak menjauhi pakan lalu diam tidak bergerak sedangkan pada kontrol, larva tetap berada pada daun kubis dan aktif makan.

Perilaku larva yang diam tak bergerak menunjukkan bahwa larva telah terinfeksi. Gejala awal yang nampak setelah larva uji memakan pakan yang mengandung $B$. thuringiensis adalah larva mulai kurang aktif dan gerakannya menjadi lamban, aktivitas makan mulai menurun. Gejala ini sesuai dengan yang dikemukakan oleh Poinar dan Thomas (1982) bahwa saluran pencernaan adalah organ yang mula-mula terserang oleh bakteri. Gejala ini terjadi akibat kerusakan membran sel epitelium midgut (Tojo, 1986). Larva yang terinfeksi kemudian mati, tubuh berubah warna dari hijau kecoklatan menjadi coklat kehitaman. Pada awal kematian larva terinfeksi tubuhnya lembek, berair dan berbau busuk. Namun demikian, setelah beberapa hari larva mulai mengering dan kemudian mengkerut. Kematian larva uji disebakan terjadinya kerusakan pada sel-sel epitel, meningkatnya permeabilitas membran sel yang pada akhirnya menyebabkan penurunan $\mathrm{pH}$ usus tengah sehingga terjadinya paralisis usus 
dan paralisis total yang diakhiri dengan kematian larva (LeBack, 1996).

\section{Patogenisitas (Nilai LC 50 dan LT50) Isolat B. thuringiensis)}

Hasil analisis probit (Tabel 1) menunjukkan bahwa semua isolat yang diuji merupakan isolat yang virulen karena kisaran patogenisitasnya adalah $10^{6}-10^{3} \mathrm{spora} / \mathrm{ml}$ karena nilai $\mathrm{LC}_{50}$ dengan kisaran $10^{9}-10^{12}$ spora/ml masih dianggap sangat potensial (Situmorang, 2009).

Berdasarkan hasil pengujian ditemukan bahwa YPPA1 merupakan isolat yang paling unggul karena mempunyai patogenisitas yang tertinggi dengan nilai $\mathrm{LC}_{50} 72 \mathrm{jam}=9,5 \times 10^{3}$ spora/ml sedangkan $\mathrm{ACH} 2.3$ merupakan isolat yang paling rendah nilai patogenisitasnya yaitu $\mathrm{LC}_{50} 72 \mathrm{jam}=2,3 \times 10^{6} \mathrm{spora} / \mathrm{ml}$. Ditinjau dari aspek kecepatan mematikan serangga uji, TUS1 merupakan isolat yang paling unggul karena mempunyai nilai $\mathrm{LT}_{50}\left(1,5 \times 10^{7}\right.$ spora/ml) terpendek yaitu 18,2 jam meskipun nilai patogenisitanya bukan yang tertinggi $\left(\mathrm{LC}_{50} 72 \mathrm{jam}=3,9 \times 10^{5}\right.$ spora $\left./ \mathrm{ml}\right)$ sedangkan SLK4.2 merupakan isolat yang paling lambat mematikan serangga uji karena nilai $\mathrm{LT}_{50}(1,5$ x $10^{7}$ spora/ml) adalah 83,2 jam dengan nilai $\left.\mathrm{LC}_{50}-72 \mathrm{jam}=3,1 \times 10^{4} \mathrm{spora} / \mathrm{ml}\right)$.

Tabel 1. Nilai $\mathrm{LC}_{50}-72$ jam dan $\mathrm{LT}_{50}\left(1,5 \times 10^{7} \mathrm{spora} / \mathrm{ml}\right)$ isolat $B$. thuringiensis terhadap $C$. binotalis.

\begin{tabular}{|c|c|c|c|c|c|}
\hline No. & Isolat & $\begin{array}{l}\text { Nilai LC } \text { L }_{50} \\
\text { (spora/ml) }\end{array}$ & $\begin{array}{c}\text { Fiducial Limit } \\
\text { (spora/ml) }\end{array}$ & $\begin{array}{c}\text { Nilai } \text { LT }_{50} \\
\text { (jam) }\end{array}$ & $\begin{array}{c}\text { Fiducial limit } \\
(\text { jam })\end{array}$ \\
\hline 1. & TUS 1 & $3,9 \times 10^{5}$ & $1,6 \times 10^{5}-1,03 \times 10^{6}$ & 18,2 & $14,6-22,7$ \\
\hline 2. & BAS 1.1 & $1,2 \times 10^{5}$ & $3,9 \times 10^{4}-3,9 \times 10^{5}$ & 28,2 & $21,7-36,6$ \\
\hline 3 & BLPPN 5.3 & $7,6 \times 10^{4}$ & $4,6 \times 10^{4}-1,2 \times 10^{5}$ & 22,9 & $18,6-28,2$ \\
\hline 4 & DGLL 5.1 & $9,6 \times 10^{5}$ & $6,0 \times 10^{5}-2,3 \times 10^{6}$ & 34,7 & $28,2-42,7$ \\
\hline 5 & BAU 6.2 & $7,1 \times 10^{4}$ & $2,8 \times 10^{4}-1,4 \times 10^{5}$ & 23,2 & $18,2-30,4$ \\
\hline 6 & SLK 4.2 & $3,1 \times 10^{4}$ & $2,4 \times 10^{4}-1,3 \times 10^{4}$ & 83,2 & $81,3-85,1$ \\
\hline 7 & ACH1.1 & $3,4 \times 10^{5}$ & $3,9 \times 10^{4}-2,9 \times 10^{6}$ & 30,9 & $19,1-38,02$ \\
\hline 8 & YWKA 1 & $2,1 \times 10^{4}$ & $1,2 \times 10^{4}-3,2 \times 10^{4}$ & 31,4 & $26,1-37,7$ \\
\hline 9 & BPSR 1. & $1,1 \times 10^{5}$ & $1,1 \times 10^{4}-2,8 \times 10^{5}$ & 24,7 & $19,1-30,9$ \\
\hline 10 & SORONG 1.3 & $5,3 \times 10^{5}$ & $3,4 \times 10^{5}-1,0 \times 10^{6}$ & 37,4 & $26,9-51,3$ \\
\hline 11 & YPPA 1. & $9,5 \times 10^{3}$ & $3,1 \times 10^{2}-2,9 \times 10^{5}$ & 24,6 & $19,9-30,2$ \\
\hline 12 & MPSQ 1. & $2,6 \times 10^{5}$ & $1,1 \times 10^{5}-5,9 \times 10^{5}$ & 24,6 & $18,6-32,4$ \\
\hline 13 & YSPB 1 & $3,6 \times 10^{5}$ & $2,2 \times 10^{5}-6,8 \times 10^{5}$ & 37,2 & $30,9-44,7$ \\
\hline 14 & MPSN 1 & $3,2 \times 10^{5}$ & $2,1 \times 10^{5}-5,3 \times 10^{5}$ & 26,3 & $19,9-34,7$ \\
\hline 15 & TKO 1 & $4,9 \times 10^{4}$ & $1,3 \times 10^{3}-1,9 \times 10^{6}$ & 30,2 & $25,1-36,3$ \\
\hline 16 & BAU 2.1 & $3,5 \times 10^{5}$ & $2,4 \times 10^{5}-5,7 \times 10^{5}$ & 36,3 & $29,0-45,4$ \\
\hline 17 & UG1A & $4,7 \times 10^{4}$ & $1,9 \times 10^{4}-1,2 \times 10^{5}$ & 29,5 & $23,9-36,0$ \\
\hline 18 & TK 9 & $8,5 \times 10^{4}$ & $4,9 \times 10^{4}-1,5 \times 10^{5}$ & 23,4 & $18,2-30,2$ \\
\hline 19 & YKAA 1.5 & $4,7 \times 10^{5}$ & $1,7 \times 10^{5}-1,3 \times 10^{6}$ & 34,7 & $28,2-42,7$ \\
\hline 20 & SOLOK 2.3 & $4,7 \times 10^{5}$ & $1,7 \times 10^{5}-1,3 \times 10^{6}$ & 30,2 & $25,1-36,3$ \\
\hline 21 & BTSKR 7.4 & $1,7 \times 10^{6}$ & $1,1 \times 10^{6}-6,5 \times 10^{6}$ & 47,3 & $40,7-57,1$ \\
\hline 22 & C 20.3 & $1,6 \times 10^{6}$ & $1,1 \times 10^{6}-3,1 \times 10^{6}$ & 47,2 & $40,7-53,7$ \\
\hline 23 & TKLR 2.2 & $3,4 \times 10^{5}$ & $2,2 \times 10^{5}-5,6 \times 10^{5}$ & 35,9 & $30,9-42,7$ \\
\hline 24 & BTMG 4.3 & $2,7 \times 10^{5}$ & $1,6 \times 10^{5}-4,9 \times 10^{5}$ & 34,7 & $28,2-42,7$ \\
\hline 25 & LPSU 4 & $1,0 \times 10^{5}$ & $5,9 \times 10^{4}-1,7 \times 10^{5}$ & 19,5 & $15,9-33,9$ \\
\hline 26 & PONTI 18.1 & $1,4 \times 10^{6}$ & $9,4 \times 10^{5}-3,1 \times 10^{6}$ & 36,5 & $30,2-43,7$ \\
\hline 27 & $\mathrm{ACH} 2.3$ & $2,3 \times 10^{6}$ & $2,5 \times 10^{5}-2,1 \times 10^{7}$ & 40,7 & $33,1-50,1$ \\
\hline 28 & LPST 1 & $7,4 \times 10^{4}$ & $1,7 \times 10^{4}-2,5 \times 10^{5}$ & 22,4 & $17,4-28,8$ \\
\hline 29 & BPSL 1 & $2,5 \times 10^{5}$ & $1,1 \times 10^{5}-5,8 \times 10^{5}$ & 26,3 & $21,4-32,4$ \\
\hline 30 & C 51 & $5,1 \times 10^{5}$ & $4,7 \times 10^{4}-4,5 \times 10^{5}$ & 28,2 & $22,4-35,5$ \\
\hline 31 & BLPPN 8.2 & $1,9 \times 10^{4}$ & $4,1 \times 10^{3}-7,7 \times 10^{4}$ & 38,0 & $31,6-45,7$ \\
\hline 32 & DGLL 3.2 & $2,0 \times 10^{5}$ & $7,8 \times 10^{4}-5,4 \times 10^{5}$ & 32,4 & $27,5-38,0$ \\
\hline 33 & BAU 3.2 & $6,3 \times 10^{4}$ & $3.3 \times 10^{4}-1,0 \times 10^{5}$ & 30,2 & $25,1-36,3$ \\
\hline 34 & SORONG 2.4 & $2,9 \times 10^{4}$ & $2,3 \times 10^{4}-9,7 \times 10^{4}$ & 28,2 & $23,4-58,9$ \\
\hline
\end{tabular}


Dengan demikian dapat disimpulkan bahwa di antara 34 isolat yang diuji ternyata isolat YPPA1 merupakan isolat yang paling unggul bila ditinjau dari aspek patogenisitasnya sedangkan dalam hal kecepatan mematikan serangga uji maka TUS1 merupakan isolat yang paling unggul. Hal ini berarti bahwa kedua isolat tersebut (YPPA1 dan TUS1) merupakan isolat unggul dan sangat potensial untuk digunakan sebagai kandidat biopestisida hayati yang ramah lingkungan.

Berdasarkan kecepatan menimbulkan kematian pada serangga uji yang dinyatakan dengan nilai $\mathrm{LT}_{50}$ maka kedua isolat unggul (YPPA1 dan TUS1) termasuk II yang menyebabkan kematian dalam waktu satu sampai empat hari (LeBack, 1996).

Walaupun YPPA1 ini merupakan strain anggota $B$. thuringiensis yang patogenik terhadap $C$. binotalis (Ordo Lepidoptera) tetapi strain ini ternyata sangat berbeda dengan strain acuan yang dikenal patogenik terhadap serangga hama anggota Ordo Lepidoptera pada umumnya yaitu $B$. thuringiensis serovar kurstaki HD1 (Dipel) baik berdasarkan hasil analisis sistematik numerik-fenetik (Salaki et al., 2009b) maupun analisis sistematik molekular-filogenetik (Sembiring et al., 2009). Oleh karena itu, isolat YPPA1 ini dapat diidentifikasi sebagai $B$. thuringiensis YPPA1 yang merupakan strain bakteri endogen Indonesia yang diduga kuat merupakan strain baru (novel strain) dalam takson spesies $B$. thuringiensis.

\section{Kesimpulan dan Saran}

\section{Kesimpulan}

Berdasarkan hasil pengujian patogenisitas dengan analisis probit maka dapat disimpulkan bahwa diantara 34 isolat potensial yang diuji diperoleh dua isolat unggul yaitu YPPA1 dan TUS1. Ditinjau dari kemampuan membunuh serangga uji maka YPPA1 merupakan isolat yang paling unggul sedangkan dalam hal kecepatan membunuh serangga uji maka isolat TUS1 yang paling unggul. Dengan demikian, kedua isolat tersebut dapat dianggap sangat potensial untuk dikembangkan sebagai kandidat biopestisida yang ramah lingkungan.

\section{Saran}

Berdasarkan hasil yang diperoleh dalam penelitian ini dapat disarankan bahwa perlu dilakukan penelitian lanjutan untuk menguji spketrum daya bunuh yang lebih luas terutama terhadap hama penting tanaman kubis misalnya Plutella xylostella, Spodoptera litura dan Spodoptera exigua. Dengan demikian dapat diketahui potensi keunggulan isolat dalam upaya pengendalian hama kubis.

\section{Ucapan Terima Kasih}

Dengan selesainya penelitian ini, kami ingin menyampaikan ucapan terima kasih pada Lembaga Penelitian dan Pengabdian pada Masyarakat UGM yang telah memberi dukungan pendanaan melalui Hibah Penelitian Mahasiswa Program Doktor 2009.

\section{Daftar Pustaka}

Bahagiawati, A. 2002. Adaptasi Serangga Hama terhadap Bacillus thuringiensis Toksin dan Protease Inhibitor. Pros. Sem. Bioteknologi Pertanian. Perhimpunan Bioteknologi Pertanian Indonesia. Jakarta

Bajwa, W.I. and Kogan, M. 2001. Bacillus thuringiensis Based Biological Control of Insect Pest. http://www.ippc.orst.edu/dir/microbial/bt/. 11/27/2008.

Burges, H.D. and Hussey, N.W. 1981. Microbial Control of Incect and Mites. Academic Press, New York.

Cahyono, B. 2002. Cara Meningkatkan Budidaya Kubis. Cetakan Ketiga. Yayasan Pustaka Nusantara.

Capinera, J.L. 2000. Plutella xylostella http://creatures.ifas.ufl.edu. 11/26/2007.

Finney, D.J. 1971. Probit Analysis. Third Edition. Cambridge University Press. Cambridge, Great Britain.

Harjaka, T. dan Suryanto. 2002. Kajian Beberapa Jamur Entomopatogenik pada Ulat Daun Kubis Hijau, Plutella xylostella. J. Perlindungan Tanaman Indonesia. 8 (2): 94-99.

Heimpel, A.M. and Angus, T.A. 1963. Disease Caused by Certain Sporeforming Bacteria. pp. 21-74. In: Steinhaus, E.A. (Ed.). Insect Pathology and Advanced Trastise, Vol. 2; Academic Press. New York. 
Hoofmann, M.P. and Frodsham, A.C. 1993. Biological Control : A Guide to Natural Enemies in North America. http://www.nysaes.cornell. edu. $12 / 11 / 2008$.

Kalshoven, L.E.G. 1981. The Pest of Crops in Indonesian. Translated by Vander Lann, P.A. P.T. Iktiar Baru Van Houve. Jakarta.

Khetan, S.K. 2001. Microbial Pest Control. Marcel Dekker, Inc. New York. USA.

LeBack, L.M. 1996. Insect Pathology in Biological Control. University of Hawaii at Manoa. Manoa, Hawai, USA.

Poinar, G.O. and Thomas, G.M. 1982. Diagnostik Manual for the Identification of Insect Pathogen. Plenum Press. New York.

Pracaya. 1992. Hama dan Penyakit Tanaman. Penebar Swadaya Jakarta.

Schellhorn, N. 2001. Crocidolomia binotalis-IPM/ CIIFAD, http://www.Agrobiological.com.

Salaki, Ch., Situmorang, J. and Sembiring, L. 2009a. Isolasi dan Karakterisasi Bakteri Indigenous Indonesia (Bacillus thuringiensis) yang Berpotensi sebagai Agensia Pengendalian Hayati terhadap Serangga Hama Kubis (Crocidolomia binotalis). Pros. Sem. Nas. Basic Science VI Fakultas MIPA Universitas Brawidjaya, Malang. 21 Februari 2009.

Salaki, Ch.L., Sembiring, L., Situmorang, J. and Handayani, N.S.N. 2009b. Diversity Analysis of Indigenous Bacillus thuringiensis Isolates Pathogenic to Crocidolomia binotalis by Using Numerical Systematic Approach. International Conference on Biological Science, Faculty of Biology, UGM. Yogyakarta. 16-17 Oktober 2009.
Sembiring, L., Salaki, Ch.L., Situmorang, J. and Handayani, N.S.N. 2009. Genetic Diversity Analysis of Indigenous Bacillus thuringiensis Isolates Pathogenic to Crocidolomia binotalis by Using Molecular Phylogenetic Approach Based on 16S rRNA Gene Sequences. International Conference on Biological Science, Faculty of Biology, UGM. Yogyakarta, 16-17 October 2009.

Situmorang, J. 2009. Komunikasi personal

Sudarwohadi, S. 1975. Hubungan antara Waktu Tanam Kubis dengan Dinamika Populasi Plutella xylostella dan Crocidolomia binotalis Zell. Bull. Penelitian. Hortikultura. 3 (4): 3-14.

Sudarwohadi, S. and Setiawati, W. 2000. Biology and Control of Crocidolomia binotalis in Indonesia. LEHRI. Lembang Indonesia.

Tojo, A. 1986. Mode of Action of Bipiramidal DeltaEndotoksin of Bacillus thuringeinsis .subs. Kurstaki HD-1. Appll. and Environmental Microbiology 51 (3): 630-633.

Trizelia. 2003. Pemanfaatan Bacillus thuringiensis untuk Pengendalian Hama Crocidolomia binotalis. Kumpulan Makalah Entomologi. Perhimpunan Entomologi Indosesia (PEI). Jakarta.

Unjianto, B. 2004. HamaUlatKantongKubisBelumBisa Diatasi.http://www.suaramerdeka.com/cybern ews/haran/0402/26/dorg.htm. 09/26/2008.

Untung, K. 1996. Dasar-dasar Pengelolaan Hama Terpadu. Fakultas Pertanian, Universitas Gadjah Mada Yogyakarta.

Untung, K. 2001. Pengantar Analisis Ekonomi Pengendalian Hama Terpadu. Gadjah Mada University Press. Yogyakarta. 